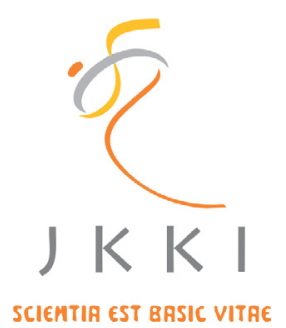

Jurnal Kedokteran dan Kesehatan Indonesia

Indonesian Journal of Medicine and Health

Journal homepage : https://journal.uii.ac.id/JKKI/index

\title{
Japanese encephalitis
}

Asri Hendrawati*1

${ }^{1}$ Department of Biochemistry, Faculty of Medicine, Universitas Islam Indonesia

\begin{tabular}{l}
\hline ARTICLE INFO \\
*Corresponding author: \\
asri_xabi@yahoo.com \\
\hline DOI:10.20885/JKKI.Vol10.Iss1.art2 \\
Copyright @2019 Authors. \\
This is an open access article \\
distributed under the terms \\
of the Creative Commons At- \\
tribution-NonCommercial 4.0 \\
International Licence (http:// \\
creativecommons.org/licences/ \\
by-nc/4.0/).
\end{tabular}

\section{EDITORIAL}

$\int \mathrm{a}$ apanese encephalitis is an infection of the brain caused by a flavivirus virus transmitted by the Culex mosquito. The infection is the most common cause of encephalitis in the Asian continent, especially in countries such as China, Taiwan, Indonesia, Cambodia, and Timor Leste. ${ }^{1}$ In Indonesia, most cases occur in Bali with the latest issue of an infection occurrence in November 2018. However, the rumor was denied by the Ministry of Health of the Republic of Indonesia due to previously launched vaccination in March 2018 to prevent the disease. ${ }^{2}$

Japanese encephalitis has varying symptoms and clinical signs, ranging from complaints of mild fever to severe meningoencephalitis. The incubation period for this disease is around 5 to 15 days, with clinical symptoms in children are usually more severe than in adults. This disease has common viral infection stage which begins with the prodromal stage, acute encephalitis and final stage. The prodromal is characterized by fever, headache, nausea, and vomiting for 2-5 days. This is followed by acute phase indicated by seizures, muscle stiffness, weakness of the limbs, and decrease in consciousness for about 1-3 weeks. The final stage is the healing stage, in which the levels of consciousness and signs of neurological disorders begin to improve., ${ }^{3,4}$

The diagnosis of Japanese encephalitis is performed based on endemic areas and clinical symptoms. Laboratory tests include the cerebrospinal fluid function, EEG, CT scan and MRI. In the analysis of cerebrospinal fluid, lymphocytic pleocytosis and an increase in the ratio of protein and glucose can be found. CT scans can show hypodense lesions in the frontotemporal area, thalamus, basal ganglia, and brain stem. The specific examination using the polymerase chain reaction (PCR) method can be used to isolate the virus DNA. Moreover, checking antibody titers against the virus can also be used to aid the diagnosis by finding a fourfold increase in the titers of antibody. ${ }^{5}$

Therapy for Japanese encephalitis consists of symptomatic and supportive therapy such as administration of fluids, antipyretics and antibiotics should there is a secondary bacterial infection. Nevertheless, previous study showed that corticosteroids and antiviral agents such as interferon- $\alpha$ do not show clinical improvement in Japanese encephalitis patients. Therefore, preventive action is an effective effort to minimize the disease incidence which can be done by eradicating vector mosquitoes that carry viruses and vaccination. ${ }^{6}$

Vaccination programs to prevent Japanese encephalitis began to be introduced in the 1990s. In 2012, as many as $75 \%$ of countries with a high risk of transmission had implemented this immunization program. The immunization has significantly reduced the incidence of the disease, therefore WHO recommends this immunization program to be included in national immunization programs in all endemic countries. ${ }^{7}$

\section{REFERENCES}

1. Batchelor P, Petersen K. Japanese encephalitis: A review of clinical guidelines and vaccine availability in Asia. Tropical Diseases, Travel Medicine and Vaccines. 2015;1(1):11. 
2. Kementerian Kesehatan Republik Indonesia. Kemenkes canangkan imunisasi cegah radang otak Japanese enchepalitis (JE). 2018.

3. Barman B, Lynrah K, Pranjal Phukan. Japanese encephalitis. In 2015. Conference paper. Conference: APICON 2016, At Hyderabad, India.

4. Basumatary LJ, Raja D, Bhuyan D, Das M, Goswami M, Kayal AK. Clinical and radiological spectrum of Japanese encephalitis. Journal of the Neurological Sciences. 2013;325(1-2):15-21.

5. Robinson JS, Featherstone D, Vasanthapuram R, Biggerstaff BJ, Desai A, Ramamurty N, et al. Evaluation of three commercially available Japanese encephalitis virus IgM enzyme-linked immunosorbent assays. The American Journal of Tropical Medicine and Hygiene. 2010;83(5):114655.

6. Swarup V, Ghosh J, Ghosh S, Saxena A, Basu A. Antiviral and anti-inflammatory effects of rosmarinic acid in an experimental murine model of Japanese encephalitis. Antimicrobial Agents and Chemotherapy.2007;51(9):3367-70.

7. WHO. Weekly epidemiological record. Japanese encephalitis: Status of surveillance and immunization in asia and the Western Pacific, 2012. 2013. 